ZBIGNIEW JAN MAKIEEA

Uniwersytet Jagielloński, Kraków, Polska - Jagiellonian University in Krakow, Poland

\title{
Znaczenie innowacyjności w gospodarce regionów
}

\section{The Importance of Innovation in the Economy of Regions}

Streszczenie: Innowacyjność jako narzędzie przedsiębiorczości jest jednym z najważniejszych zasobów wpływających na tempo procesów gospodarczych. Skupia się ona w głównej mierze na określaniu pozycji konkurencyjnej przedsiębiorstw, sektorów gospodarki, poszczególnych państw, regionów, gmin oraz integrujących się krajów. Innowacyjność gospodarki określa się najczęściej jako motywację uczestników procesów gospodarczych do ciągłego poszukiwania nowych wyników badań, nowych koncepcji i pomysłów do wytwarzania ulepszonych urządzeń, materiałów oraz usług kierowanych na rynek. Innowacyjność regionu jest funkcją takich cech, jak: motywacja, zdolności przedsiębiorstw do poszukiwania nowych pomysłów, koncepcji i wynalazków oraz ulepszania już powstałych, współpracy między przedsiębiorstwami, lokalnych umiejętności i doświadczeń, współpracy sfery publicznej z przedsiębiorstwami, współpracy nauki z przedsiębiorstwami. Efektywność tych powiązań przenosi się na stopień generowania oraz absorpcji innowacji w regionie. Przedmiotem niniejszego opracowania jest określenie znaczenia innowacyjności w gospodarce regionów. Celem stało się wskazanie roli innowacji w procesie konkurencyjności regionów. Pomiar innowacyjności jest bowiem istotnym narzędziem różnicowania regionów, pozwalającym wskazać na obszary, od których zależy ich poziom rozwoju. Z przeprowadzonej analizy wynika, że w procesie tworzenia nowych technologii, przenikania innowacji i zarządzania transferem, najważniejsza jest współpraca przedsiębiorstw i naukowców, będąca podstawowym poziomem wzajemnych relacji w regionie. Władza samorządowa nie uczestniczy bezpośrednio w tworzeniu technologii, ale odgrywa bardzo ważną rolę w tworzeniu warunków do kształtowania GOW, często też sama kreuje transfer technologii z nauki do biznesu.

Abstract: Innovation as an entrepreneurial tool is one of the most important resources influencing the pace of economic processes, focusing primarily on determining the competitive position of enterprises, sectors of economy, individual states, regions, municipalities and integrating countries. Business innovation is most often referred to as the motivation of business process participants to continually seek new research and new ideas, to produce improved equipment, materials, and services targeted to the marketplace. Innovation of the region is a function of motives, the ability of companies to seek new ideas, concepts and inventions, and to improve existing ones, co-operation between enterprises, local skills and experience, co-operation between the public sphere and enterprises, co-operation between science and business. The efficiency of these relationships is transferred to the degree of generation and absorption of innovation in the region. The subject of the study is to determine the importance of innovation 
in the economy of regions. The aim of the study is to show the role of innovation in the process of regions' competitiveness. Measurement of innovation is an important tool for diversifying regions, allowing to indicate the areas on which their level of development depends The analysis shows that in the process of creating new technologies, infiltration of innovations, transfer management, the most important is the cooperation of enterprises and scientists, which is the basic level of mutual relations in the region. Local government does not participate directly in the creation of technology, but it plays a very important role in creating the conditions for shaping the KBE, often it creates the transfer of technology from science to business.

Słowa kluczowe: gospodarka oparta na wiedzy; innowacje; pomiar innowacyjności; region

Keywords: innovation; knowledge-based economy; measurement of innovation; region

Otrzymano: 3 listopada 2017

Received: 3 November 2017

Zaakceptowano: 8 czerwca 2018

Accepted: 8 June 2018

\section{Sugerowana cytacja/Suggested citation:}

Makieła, Z.J. (2018). Znaczenie innowacyjności w gospodarce regionów. Przedsiębiorczość Edukacja [Entrepreneurship - Education], 14, 40-48. DOI: 10.24917/20833296.14.3

\section{Wstęp}

Znaczenie przedsiębiorczości i innowacyjności w budowaniu przewagi konkurencyjnej regionu jest powszechnie uznawane przez aktorów tworzących zbiór regionalnych podmiotów. W rozwiniętej gospodarce rynkowej podmioty gospodarcze, miasta i regiony konkurują ze sobą o pozyskanie czynników rozwoju, które pozwolą im na uzyskanie trwałej przewagi konkurencyjnej. Jednym z ważniejszych współcześnie czynników rozwoju jest przedsiębiorczość mieszkańców, menadżerów i właścicieli przedsiębiorstw. Z przedsiębiorczością ściśle powiązana jest innowacyjność. Innowacja to proces polegający na przekształcaniu istniejących możliwości w nowe idee i wdrażaniu ich w praktykę. Regiony dążące do poprawy poziomu innowacyjności dokonują wyboru drogi pozyskiwania innowacji. Inwestują w wiedzę, rozwój nauki, rozwój uczelni, w sektor badawczo-rozwojowy, który osiąga efekty inwestycyjne wprawdzie rozłożone w czasie i wdrażane z pewnym opóźnieniem, ale długotrwale i skutecznie.

Region innowacyjny to region, który skutecznie tworzy klimat innowacyjnych zachowań podmiotów sfery produkcji i usług, organizacji i jednostek samorządu terytorialnego, aktywnie zachęcając lokalne społeczności do włączenia się w ten proces. Posiada potencjał $\mathrm{B}+\mathrm{R}$, który jest gotowy do prowadzenia badań naukowych, współpracy z podmiotami regionu oraz wdrażania efektów badań naukowych do gospodarki.

W literaturze przedmiotu pojęcie innowacyjności regionu utożsamiane jest przeważnie $\mathrm{z}$ innowacyjnością gospodarki. Wydaje się to być uproszczeniem. Rozszerzając tę definicję, warto zwrócić uwagę na koncepcję innowacyjnego środowiska, wprowadzoną przez francuskiego regionalistę, Ph. Aydalota (Aydalot, 1986). Źródeł innowacji upatruje on nie w przedsiębiorstwie, ale w środowisku, w którym ono funkcjonuje. Idea ta pokazuje terytorialny charakter procesu rozwoju innowacji. Środowisko jest innowacyjne, gdy wchodzi w relacje z otoczeniem, korzysta z lokalnych umiejętności, które na pewnym etapie staną się umiejętnościami specyficznymi dla tego środowiska i utworzą jego przewagę konkurencyjną. 
Celem konkurencyjnych regionów jest tworzenie sprzyjających warunków do pobudzania przedsiębiorczości i innowacyjności, wynikających z organizacji przestrzennej regionu, której konsekwencją jest zrównoważony rozwój całej gospodarki. W literaturze krajowej i zagranicznej zwraca się uwagę na rolę przedsiębiorczości i innowacyjności w procesach rozwoju regionalnego i lokalnego oraz wpływ zróżnicowanych warunków ekonomicznych na przedsiębiorczość i innowacyjność.

Niniejsze opracowanie ma na celu wskazanie roli innowacji w konkurencyjności regionów. Pomiar innowacyjności pozwala wskazać na obszary, od których zależy poziom rozwoju danego regionu. Rola innowacyjności w procesach gospodarczych skupia się w głównej mierze na określaniu pozycji konkurencyjnej przedsiębiorstw, sektorów gospodarki, poszczególnych państw, regionów, gmin oraz integrujących się krajów. Zdaniem M.E. Portera (Porter, 2001), przewagę konkurencyjną określonych terytoriów osiąga się właśnie przez działania innowacyjne.

Interesującą jest teoria mówiąca, że wśród czynników warunkujących rozwój organizacji uczących się znajdują się czynniki regionalne, które nazywa się regionalnym laboratorium wiedzy (regional knowledge laboratory) (Langendijk, 2001).

Podobny pogląd (Pfirrmann, 1994) wskazuje, że działania innowacyjne małych i średnich przedsiębiorstw są kształtowane przez czynniki regionalne. Kolejni autorzy (Oughton, Landabaso, Morgan, 2002) uważają, że na innowacyjne działania przedsiębiorstw oraz ich rozwój w dużej mierze wpływają czynniki regionalne. Fenomen ten nazywają regionalnym paradoksem innowacyjnym.

\section{Czynniki rozwoju regionu}

Dla rozwoju gospodarczego regionu ma znaczenie wiele czynników, które pojedynczo mają różną siłę oddziaływania, ale po skumulowaniu wielu z nich można uzyskać dodatnie wyniki. Poniżej zostaną przedstawione niektóre z nich, niekoniecznie o hierarchicznym znaczeniu dla wzrostu gospodarki regionu (Markowski, 2005). Są to:

- powiązania sieciowe podmiotów regionalnych - wyższych uczelni, instytucji biznesu, instytucji społecznych, instytucji finansowych, przedsiębiorstw, grup społecznych tworzących kapitał społeczny, instytucji sprzyjających aktywizacji przedsiębiorczości i innowacyjności. Powiązania sieciowe o charakterze wewnętrznym i zewnętrznym (dyfuzja), kształtują normy życia społecznego (tolerancja regionalna), określają standardy zachowań podmiotów, premiują regiony o wysokich standardach kapitału ludzkiego (talent regionu) oraz wiedzę i przepływ innowacji w obszarze nauka - biznes, tj. innowacyjność regionalną (technologia);

- innowacyjność władz samorządowych wyrażana dojrzałością zarządzania. Tworzenie regionalnych podmiotów samorządowych, których celem jest rozwój nowoczesnych sektorów gospodarki. Budowanie struktur zarządzania na podstawie partnerstwa publiczno-prywatnego, odpowiedzialnego za pobudzanie przedsiębiorczości i tworzenie dla przedsiębiorczości instrumentów wspomagania finansowego, doradczego, organizacyjnego. Branie przez samorząd terytorialny odpowiedzialności za tworzenie warunków dla działalności gospodarczej przez budowę systemów infrastruktury technicznej, kształtowanie pozytywnego klimatu inwestycyjnego, ograniczanie biurokracji, budowę pozytywnego wizerunku gminy, regionu; 
- dbałość przez elity samorządowe o pozycję konkurencyjną regionu przez wspieranie rozwoju i specjalizację lokalnych firm dla wzmocnienia ich pozycji na rynku krajowym i międzynarodowym. Wspieranie - finansowanie badań innowacyjnych w uniwersytetach, w celu przepływu innowacji do gospodarki regionu, wspieranie rynkowych kierunków kształcenia, organizowanie projektów badawczych partnerstwa publiczno-prywatnego (PPP - Public Private Partnership);

- kultura organizacyjna administracji samorządowej przejawiająca się skutecznym działaniem, budowanie wizerunku wysokich standardów obsługi, realizacja działań wynikających z ustalonych kierunków polityki regionalnej, budowanie kadr administracyjnych cechujących się wysokimi standardami obsługi i wiedzy specjalistycznej z zakresu spraw publicznych;

- dbanie o wartości ogólnospołeczne i wysoki poziom życia mieszkańców przez budowanie instytucji zajmujących się promowaniem wartości kulturowych regionu, dbałość o relacje społeczne i budowanie struktur elit regionalnych, promowanie społecznej spójności i tożsamości regionalnej.

Czynniki zewnętrzne tkwiące $\mathrm{w}$ otoczeniu małych i średnich przedsiębiorstw dzielą się na czynniki regionalne oraz ponadregionalne (supra-regional). Możliwe jest dokładne rozgraniczenie czynników otoczenia regionalnego, czynników makrootoczenia oraz czynników związanych z polityką innowacyjną, które zaliczyć można zarówno do czynników regionalnych, jak i ogólnych (Sternberg, Arndt, 2000).

Do podstawowych czynników sprzyjających rozwojowi regionalnemu zaliczono: innowacyjność technologiczną i organizacyjną, kapitał ludzki, materialny, finansowy i społeczny oraz zewnętrzne przepływy osób, kapitału i towarów (Churski, 2008). Najważniejsze z nich, wpływające bezpośrednio na poziom konkurencyjności przedsiębiorstw, miast, układów lokalnych i regionalnych, to innowacyjność i przedsiębiorczość. Innowacyjność ma zasadnicze znaczenie dla konkurencyjności podmiotów regionalnych, zwłaszcza w dobie globalizacji. Podmioty regionalne nie tylko kumulują wiedzę przez badania naukowe i rozwój technologii, ale także poszukują nowych rozwiązań np. w zakresie marketingu i zarządzania. Aby zachować przewagę konkurencyjną, przedsiębiorstwa wykazują się większą pomysłowością i więcej inwestują w innowacje.

Innowacje technologiczne i organizacyjne uważane są za główny czynnik rozwoju regionalnego we wszystkich modelach rozwoju. Chodzi tu o wszystkie formy innowacyjności gospodarki, rozwiązania techniczne i technologiczne, nowe formy organizacyjne, instytucjonalne i zarządcze. Czynnikami wspierającymi proces przedsiębiorczości i innowacyjności regionalnej są kapitał ludzki, kapitał społeczny, kapitał materialny, kapitał finansowy (Churski, 2008), zewnętrzne przepływy osób, kapitału i towarów:

- kapitał ludzki jako najważniejszy rodzaj kapitału we współczesnych procesach rozwojowych jest tworzony przez część zasobów ludzkich aktywnie lub potencjalnie uczestniczących w działalności społeczno-gospodarczej ze względu na posiadaną wiedzę, kwalifikacje i umiejętności. Aspekty kapitału ludzkiego to sytuacja demograficzna regionu, poziom wykształcenia i dostęp do usług edukacyjnych oraz sytuacja na rynku pracy;

- kapitał społeczny jako nowa kategoria kapitału wpływającego na rozwój regionalny składa się z norm, wartości, aktywności społecznej i więzi pomiędzy grupami społecznymi i w ten sposób wpływa na rozwój przedsiębiorczości oraz konkurencyjności regionu. Specyfika tego rodzaju kapitału sprawia, że jest on trudno kwantyfikowalny. 
Kapitał społeczny należy rozpatrywać w aspektach: aktywności społecznej, działalności organizacji pozarządowych oraz przedsiębiorczości;

- kapitał materialny obejmuje dobra materialne przeważnie o charakterze środków trwałych, będących podstawą prowadzenia działalności gospodarczej. Aspekty charakterystyczne dla kapitału materialnego to zwłaszcza zasoby naturalne i stan środowiska przyrodniczego, infrastruktura techniczna, infrastruktura społeczna i środki trwałe przedsiębiorstw;

- kapitał finansowy to całość wolnych środków finansowych, które mogą być przeznaczone na realizację nowych inwestycji powiększających kapitał materialny regionu, oraz środki przeznaczone przez mieszkańców na konsumpcję zwiększającą popyt wewnętrzny. Kapitał finansowy jako czynnik rozwoju regionalnego bada się, przyjmując za kryterium sytuację finansową samorządu terytorialnego i przedsiębiorstw, fundusze Unii Europejskiej, dochody ludności oraz poziom inwestycji;

- zewnętrzne przepływy osób, kapitału i towarów są obecnie uważane za uzupełniający czynnik rozwoju regionalnego. Buduje on działalność egzogeniczną regionu i sprzyja rozwojowi jego działalności endogenicznej. Analizę tego czynnika przeprowadza się na podstawie determinujących aspektów, migracji, inwestycji zagranicznych i handlu zagranicznego.

Innowacyjność uznawana jest jako jedna z koncepcji rozwoju regionów, gospodarki regionalnej, sieci osadniczej i struktur organizacyjnych samorządu terytorialnego. Uczestnicy gry rynkowej dla uzyskania przewagi konkurencyjnej korzystają z wielu aspektów przedsiębiorczości i innowacyjności, tj. z kreatywności, gospodarki opartej na wiedzy, pozyskiwaniu regionalnych czynników rozwojowych, atrakcyjności lokalizacyjnej i konkurencyjności terytorialnej, konkurencyjności regionów, wiedzy jako strategii rozwoju regionalnego, przedsiębiorczości, innowacyjności jako: koncepcji rozwoju kapitału ludzkiego i kapitału społecznego oraz koncepcji aktywności mieszkańców, jako wizerunku przedsiębiorstw, miast, jednostek osadniczych i regionów, a także jako narzędzi wpływania na decyzje inwestorów (Makieła, 2013).

Tak rozumiana rola przedsiębiorczości i innowacyjności we wzroście struktur regionalnych spowodowała, że rozwinął się nurt badań, który konstatuje, że największym potencjalnym zasobem warunkującym rozwój i uzyskanie przewagi konkurencyjnej jest wiedza, zaś przedsiębiorczość i innowacyjność stanowią emanację wiedzy, są główną siłą napędową wzrostu i rozwoju społeczno-ekonomicznego regionu. Skutkiem wdrażania przedsiębiorczości i innowacyjności przez podmioty jest poprawa ich efektywności oraz konkurencyjności. Następuje to w wyniku ich rozwoju ilościowego i jakościowego, modernizacji, restrukturyzacji sektorowej oraz przestrzennej, a zdobywanie przewagi konkurencyjnej podmiotów na rynkach przekłada się na uzyskiwane korzyści (Marszał, 2012).

Regiony określane jako terytorialne systemy produkcyjne bądź środowiska innowacyjne są źródłem przewagi konkurencyjnej dla skupionych tam mikro-, małych i średnich przedsiębiorstw, zwłaszcza rodzinnych i rzemieślniczych. Zapewnienie na poziomie regionalnym warunków niezbędnych do istnienia środowiska innowacyjnego prowadzi do kreowania przedsiębiorstw innowacyjnych, czyli powstawania innowacyjnych firm będących emanacją lokalnego środowiska (Kosała, Wach, 2011). 


\section{Pomiar innowacyjności}

Model innowacyjnego środowiska akcentuje znaczenie interakcji zachodzących między podmiotami gospodarczymi, polegających na wzajemnym uczeniu się oraz szukaniu wspólnie rozwiązań różnych problemów.

Współpraca odbywa się w określonej przestrzeni geograficznej i ma formę sieci. Sama współpraca przedsiębiorstw może jednak okazać się niewystarczająca, aby region mógł efektywnie generować i absorbować wiedzę oraz innowacje, dlatego od dawna w literaturze podkreśla się znaczenie czynnika publicznego, sfery działalności badawczo-rozwojowej czy instytucji pośredniczących w transferze innowacji (tzw. złoty trójkąt).

Główną siłą rozwoju jest wiedza ludzi, którą można podzielić na wiedzę skodyfikowaną (codified knowledge) i cichą (tacit knowledge). Wiedza skodyfikowana to wiedza zapisana i przechowywana w różny sposób, np. w książkach, zasobach World Wide Web, w raportach itp. Wiedza cicha jest nierozerwalnie związana $\mathrm{z}$ ludźmi, $\mathrm{z}$ ich talentami, doświadczeniem i zdolnościami; wiedzę tę można przekazać jedynie w drodze bezpośrednich kontaktów. Wiedza stanowi największy strategiczny zasób, a uczenie się (poznawanie) jest najważniejszym procesem.

Region, przez swoje specyficzne zasoby, do których zaliczyć można: zasób wiedzy, zdolność uczenia się, kulturę organizacyjną, infrastrukturę i wiele innych, wpływa na konkurencyjność lokalnych przedsiębiorstw oraz na ich aktywność innowacyjną. Te konkurencyjne przewagi, mające charakter lokalny, płyną z koncentracji wysoko wyspecjalizowanej wiedzy, obecności instytucji publicznych, konkurencji, partnerów handlowych i konsumentów (Florida, 2000).

W celu zbadania zróżnicowania województw/regionów pod względem poziomu innowacyjności proponuje się przyjąć osiem komponentów, którymi są: kapitał ludzki, finansowanie i wsparcie, aktywność przedsiębiorstw, powiązania przedsiębiorcze, ochrona własności intelektualnej, innowatorzy, efekty ekonomiczne, reprezentowane przez cechy statystyczne. Według autora niniejszego opracowania, komponenty te pozwolą na zdiagnozowanie zróżnicowania potencjału innowacyjności województw oraz określenie, który z komponentów jest najsłabszym ogniwem innowacyjności, a zarazem barierą utrudniającą budowanie przewagi konkurencyjnej. Są one elementem autorskiej koncepcji pozyskiwania regionalnych czynników rozwojowych jako nowoczesnej koncepcji rozwoju regionalnego (Makieła, 2013):

\section{Kapital ludzki:}

- pracujący w sektorze działalności badawczo-rozwojowej na 1000 osób aktywnych zawodowo,

- udział (\%) osób z wykształceniem wyższym w grupie wiekowej 25-35 lat,

- udział (\%) studentów szkół publicznych na kierunkach inżynieryjno-technicznych w grupie wiekowej 18-25 lat,

- udział (\%) uczniów i studentów w grupie wiekowej 25-35 lat,

- udział (\%) uczniów korzystających z internetu,

- absolwenci kierunków ścisłych i technicznych na 1000 mieszkańców w grupie wiekowej 25-35 lat,

- osoby ze stopniem doktora nauk na 1000 mieszkańców w naukach ścisłych, w grupie wiekowej 25-35 lat, 
- udział (\%) osób z tytułem doktora habilitowanego w szkołach wyższych w grupie doktorów nauk,

- udział (\%) profesorów wyższych szkół technicznych w grupie pracowników naukowych.

Finansowanie sektora $B+R$ :

- udział (\%) wydatków publicznych na B+R w PKB,

- udział (\%) inwestycji i kredytów prywatnych w PKB,

- nakłady na B+R w szkolnictwie wyższym (mln zł),

- nakłady na B+R na 1 mieszkańca (zł),

- nakłady na B+R na 1 pracującego w sektorze B+R (tys. zł),

- udział (\%) nakładów na działalność B+R do PKB.

Finansowanie w sektorze przedsiębiorstw:

- udział (\%) wydatków przedsiębiorstw na B+R do PKB,

- udział (\%) wydatków na innowacyjne technologie do PKB,

- udział (\%) nakładów na działalność innowacyjną przedsiębiorstw przemysłowych ze środków własnych (tys. zł),

- nakłady na działalność innowacyjną przedsiębiorstw przemysłowych ze środków budżetowych (tys. zł),

- nakłady na działalność B+R w sektorze przedsiębiorstw (mln zł),

- udział (\%) przedsiębiorstw, które wprowadziły innowacje w grupie przedsiębiorstw.

Kapitał relacyjny w sektorze MŚP:

- udział (\%) MŚP prowadzących działalność B+R i wdrażających autorskie innowacje w ogólnej liczbie MŚP,

- udział (\%) MŚP współpracujących z sektorem nauki w ogólnej liczbie MŚP,

- udział (\%) MŚP w strukturach klastrowych w ogólnej liczbie przedsiębiorstw,

- udział (\%) MŚP w parkach technologicznych w ogólnej liczbie przedsiębiorstw.

Własność intelektualna:

- liczba wynalazków zgłoszonych do ochrony patentowej w Europejskim Urzędzie Patentowym na 1 mln mieszkańców,

- liczba znaków towarowych zgłoszonych na 1 mln mieszkańców,

- liczba wzorów użytkowych zgłoszonych na 1 mln mieszkańców.

Kategorie innowacyjnych przedsiębiorstw:

- innowacje produktowe wdrożone w przedsiębiorstwach na 100 przedsiębiorstw,

- innowacje organizacyjne wdrożone w przedsiębiorstwach na 100 przedsiębiorstw,

- innowacje marketingowe wdrożone w przedsiębiorstwach na 100 przedsiębiorstw,

- innowacje technologiczne wdrożone w przedsiębiorstwach na 100 przedsiębiorstw,

- innowacje ekologiczne wdrożone w przedsiębiorstwach na 100 przedsiębiorstw.

Efektywność ekonomiczna:

- udział (\%) eksportu innowacyjnych produktów do eksportu ogółem,

- udział (\%) sprzedaży nowych wyrobów lub zmodernizowanych wyrobów w sprzedaży przedsiębiorstw ogółem.

Na podstawie zaproponowanych komponentów innowacyjności możemy dokonać oceny poziomu zróżnicowania regionów, ich hierarchizacji, struktury innowacyjności, co może być wsparciem w procesie poszukiwania rozwiązań funkcjonalnych, mających na celu przebudowę struktur regionalnych, poszukiwanie innowacyjnych zasobów regionalnych oraz podejmowanie działań dla klimatu innowacyjności. 
Zorientowanie rozwoju jednostek osadniczych, metropolii, miast oraz jednostek samorządowych na koncepcje rozwoju przedsiębiorczości i innowacyjności wynika z ich specyficznych cech. Jednostki samorządu terytorialnego różnią się:

- zasobami ludzkimi (ludzie i ich specyficzne predyspozycje - jakość kapitału ludzkiego i kapitału społecznego),

- zasobami naturalnymi (np. ziemia, surowce, wielkość powierzchni),

- zasobami kapitałowymi (wartości rzeczowe i finansowe wytworzone przez człowieka, potrzebne do produkcji, zainwestowany kapitał finansowy),

- zasobami organizacyjnymi,

- potencjałem przedsiębiorczości i innowacyjności,

- inteligentnymi specjalizacjami,

- wiodącymi funkcjami i rangą w strukturze hierarchicznej.

\section{Podsumowanie}

Rosnące znaczenie wiedzy i informacji w procesach gospodarczych sprawiło, że podmiotem gospodarki regionalnej są struktury gospodarki opartej na wiedzy, skupione w tzw. złotym trójkącie wyznaczanym przez naukę, administrację samorządową i przedsiębiorstwa. Gospodarka oparta na wiedzy wymusza wzmacnianie innowacyjności lokalnej gospodarki regionu, gminy oraz miasta. Współpraca lokalnych podmiotów w złotym trójkącie koncentruje się przede wszystkim na tworzeniu innowacyjnych technologii i późniejszej ich komercjalizacji na rynkach.

Gospodarka oparta na wiedzy (Gaczek, 2009) skoncentrowana jest na wielu ważnych aspektach - wiedzy, przedsiębiorczości, innowacjach, efektywności i konkurencji. Ponadto skupia się ona na produktywności i konkurencyjności przedsiębiorstw, miast, regionów oraz państw. Z kolei o pozycji konkurencyjnej decyduje innowacyjność gospodarki oraz polityka innowacyjna państwa. O roli innowacyjności i jej znaczeniu w procesach rozwoju społeczno-gospodarczego świadczy to, że innowacje są odpowiedzialne za dwie trzecie wzrostu gospodarek wysoko rozwiniętych.

W procesie tworzenia nowych technologii, przenikania innowacji oraz zarządzania transferem najważniejsza jest współpraca przedsiębiorstw i naukowców, będąca podstawowym poziomem wzajemnych relacji w regionie. Władza samorządowa nie uczestniczy bezpośrednio w tworzeniu technologii, ale odgrywa bardzo ważną rolę w tworzeniu warunków do kształtowania GOW, często też sama kreuje transfer technologii z nauki do biznesu.

Literatura

References

Aydalot, Ph. (1986). L'aptitude des milieux á promouvair l'innovation. Paris: Economia.

Churski, P. (2008). Czynniki rozwoju regionalnego i polityka regionalna w Polsce w okresie integracji z UE. Poznań: Wydawnictwo Naukowe UAM.

Dąbrowska, A., Dziemianowicz, W. (2012). Doświadczenia polskich miast w rozwoju opartym na innowacjach - rola administracji samorządowej. W: Z. Makieła, A. Szromnik (red.), Miasto innowacyjne, wiedza, przedsiębiorczość, marketing. Warszawa: Studia KPZK PAN, t. CXLI, 153-168.

Florida, R. (2000). The Learning Region. W: Z.J. Acs (red.), Regional Innovation, Knowledge and Global Change. New York, 58-72.

Gaczek, W.M. (2009). Gospodarka oparta na wiedzy w regionach europejskich. Warszawa: Studia KPZK PAN, t. CXVIII. 
Kosała, M., Wach, K. (2011). Regionalne determinanty rozwoju innowacyjnych przedsiębiorstw. Zeszyty Naukowe Uniwersytetu Ekonomicznego w Krakowie, 866, 157-159.

Langendijk, H.P.A.J. (2001). Fair value en/of kostprijs voor waardering en winstbepaling. Accountant Adviseur, 6, 82-84.

Makieła, Z. (2013). Przedsiębiorczość i innowacyjność terytorialna. Region w warunkach konkurencji. Warszawa: C.H. Beck.

Markowski, T., Kot, J., Stawasz, E. (1976). Regionalne systemy innowacji jako podstawa budowania konkurencyjności polskich regionów. Samorzą Terytorialny, 6, 46-48.

Marszał, T. (2012). Miasto innowacyjne - koncepcja i uwarunkowania rozwoju. W: Z. Makieła, A. Szromnik (red.), Miasto innowacyjne - wiedza - przedsiębiorczość - marketing. Warszawa: Studia KPZK PAN, t. CXLI, 17-29.

Oughton, Ch., Landabaso, M., Morgan. K. (2002). The Regional Innovation Paradox: Innovation Policy and Industrial Policy. Journal of Technology Transfer, 27(1).

Pfirrmann, O. (1994). The Geography of Innovation in Small and Medium-Sized Firms in West Germany. Small Business Economics, 6(1).

Porter, M.E. (2001). Porter o konkurencji. Warszawa: PWE.

Sternberg, R., Arndt O. (2000), The Firm or the Region - What Determines European Firms' Innovation Behavior?. Working Paper nr 2, Cologne: University of Cologne, Department of Economic and Social Geography.

Zbigniew Jan Makieła, prof. dr hab., kierownik Katedry Organizacji i Zarządzania, Uniwersytet Jagielloński. Profesor nauk ekonomicznych - Uniwersytet Ekonomiczny w Krakowie, dr hc Tarnopolskiego Instytutu Społecznych i Informacyjnych Technologii, kierownik Katedry Organizacji i Zarządzania, przewodniczący Rady Instytutu Ekonomii, Finansów i Zarządzania, absolwent Uniwersytetu Pedagogicznego w Krakowie. Autor kilkunastu książek i ponad 180 zwartych artykułów naukowych. Specjalizuje się w zakresie przedsiębiorczości i zarządzania innowacjami, gospodarka przestrzenna. Odznaczenia: Medal Komisji Edukacji Narodowej i Złoty Krzyż Zasługi. Wyróżnienia: 4 Nagrody Ministra Nauki i Szkolnictwa Wyższego, w latach 2007-2011. Rektor Państwowej Wyższej Szkoły Techniczno-Ekonomicznej im. Ks. B. Markiewicza w Jarosławiu. Odbył staż naukowy w Harvard University Extension School.

Zbigniew Jan Makieła, professor, Head of the Chair of Organization and Management, Jagiellonian University. Professor of Economics - Cracow University of Economics, Doctor honoris causa of Ternopil Institute for Social and Information Technology. Employed at the Jagiellonian University in Krakow, Faculty of Management and Social Communication, Institute of Economics, Finance and Management, Department of Organization and Management, graduated from the Pedagogical University of Cracow. The author of several books and more than 180 articles. Specialises in the field of entrepreneurship and innovation management, spatial economy. He was awarded with: Medal of the National Education Commission, Gold Cross of Merit, 4 awards of the Minister of Science and Higher Education, in the years 2007-2011. Rector of the B. Markiewicz State Higher School of Technology and Economics in Jarosław. He took part in an internship organised by the of Harvard University Extension School, session Executive Speaker Training taught by faculty from the Harvard Extension School as part of the program on Management of Higher Education Institutions (January/February 2010).

\section{Adres/Address:}

Uniwersytet Jagielloński

Wydział Zarządzania i Komunikacji Społecznej

Instytut Ekonomii, Finansów i Zarządzania

Katedra Organizacji i Zarządzania

ul. prof. Stanisława Łojasiewicza 4

30-348 Kraków, Polska

e-mail: zbigniew.makiela@uj.edu.pl 